\title{
The genetic basis of deafness in populations of African descent
}

Jason R. Rudman ${ }^{1, \#}$, Rosemary I. Kabahuma, ${ }^{2, \#, *}$, Sara E. Bressler ${ }^{1}$, Yong Feng ${ }^{3}$, Susan H. Blanton $^{1,4,5}$, Denise Yan ${ }^{1}$, Xue-Zhong Liu ${ }^{1,3,4,5, *}$

1. Department of Otolaryngology, University of Miami Miller School of Medicine, Miami, FL 33136, USA

2. Department of Otorhinolaryngology, Steve Biko Academic Hospital, University of Pretoria, Pretoria 0001, South Africa

3. Department of Otolaryngology, Xiangya Hospital, Central South University, Changsha 410008, China

4. Dr. John T. Macdonald Foundation Department of Human Genetics, University of Miami Miller School of Medicine, Miami, FL 33136, USA

5. John P. Hussman Institute for Human Genomics, University of Miami Miller School of Medicine, Miami, FL 33136, USA

\# These two authors contributed equally to this work.

* Correspondence authors

E-mail: x.liu1@med.miami.edu (X. Liu), kabahumar2@gmail.com (R. Kabahuma) 


\begin{abstract}
Hearing loss is the most common sensorineural disorder worldwide and is associated with more than 1000 mutations in more than 90 genes. While mutations in genes such as GJB2 (gapjunction protein $\beta 2$ ) and GJB6 (gap-junction protein $\beta$ 6) are highly prevalent in Caucasian, Asian, and Middle Eastern populations, they are rare in both native African populations and those of African descent. The objective of this paper is to review the current knowledge regarding the epidemiology and genetics of hearing loss in African populations with a focus on native sub-Saharan African populations. Environmental etiologies related to poor access to healthcare and perinatal care account for the majority of cases. Syndromic etiologies including Waardenburg, Pendred, and Usher syndromes are uncommon causes of hearing loss in these populations. Of the non-syndromic causes, common mutations in GJB2 and GJB6 are rarely implicated in populations of African descent. Recent use of next-generation sequencing (NGS) has identified several candidate deafness genes in African populations from Nigeria and South Africa that are unique when compared to common causative mutations worldwide. Researchers also recently described a dominant mutation in $M Y O 3 a$ in an African American family with nonsyndromic hearing loss. The use of NGS and specialized panels will aid in identifying rare and novel mutations in a more cost and time effective manner. The identification of common hearing loss mutations in indigenous African populations will pave the way for translation into genetic deafness research in populations of African descent worldwide.
\end{abstract}

Keywords: Genetic; Hearing loss; Deafness; African 


\section{Introduction}

Hearing loss is the most common congenital sensorineural disorder worldwide, affecting about 1 in 1,000 children. In the US, genetic factors are responsible for approximately half of the cases of hearing loss (Mustapha et al., 2001), of which 30\% are associated with syndromic causes and $70 \%$ are considered non-syndromic hearing loss (NSHL) - i.e., deafness alone with no associated features suggesting a clinical syndrome (Van Camp et al., 1997).

NSHL has been studied worldwide and more than 1000 mutations on over 90 genes have been identified, demonstrating that NSHL is highly heterogeneous (Van Camp et al., 1997; Van Camp and Smith, 2016). Mutations in the GJB2 (gap-junction protein $\beta$ 2) gene (13q11-q12) account for a high proportion of these cases in many populations and explain up to $50 \%$ of cases in the Mediterranean regions (Gasparini et al., 1997; Kelsell et al., 1997; Estivill et al., 1998). Specific GJB2 mutations occur preferentially, but not exclusively, in distinct ethnic groups. The deletion variant g.3352GdelG (commonly designated c.30delG or c.35delG), for example, is by far the most frequent cause of autosomal recessive non-synd romic deafness among Caucasians (Zelante et al., 1997; Brobby et al., 1998; Kelley et al., 1998). Other frequent population-specific GJB2 mutations include c.167delT in Ashkenazi Jews (Morell et al., 1998; Idan et al., 2013) and c.235delC in East Asians (Japanese, Koreans, and Chinese) (Abe et al., 2000; Park et al., 2000; Yan et al., 2003; Dai et al., 2009). On the other hand, the GJB6 (gap-junction protein $\beta$ 6) deletion mutation del(GJB6-D13S1830) is common in France, Spain, the United Kingdom and Israel, accounting for $6 \%-10 \%$ of all DFNB1 alleles (Del Castillo et al., 2003). Their identification has dramatically improved the clinical diagnosis and management of deaf and hard-of-hearing families. However, causative variants are found in less than $40 \%$ of cases, leaving a significant portion of deaf individuals (>60\%) without a molecular diagnosis. This is significantly higher in US minorities that include African Americans (Shearer et al., 2013; Bademci et al., 2016; Yan et al., 2016). There is a very low frequency of deafness-causing variants in GJB2/GJB6 in African American populations (Samanich et al., 2007). Likewise, Afro-Brazilians have a low incidence of specific GJB2 mutations (c.35DelG) (Oliveira et al., 2004). In general, specific genetic causes of NSHL in populations of African descent have been more elusive. 
There is therefore a need to identify genetic causes of hearing loss in populations of African descent. With recent developments in high-throughput sequence capture methods and nextgeneration sequencing (NGS), technologies now allow for the complete analysis of all known deafness-causing genes. Given the relative rarity of known deafness-causing genes in populations of African descent and the recent acceleration in identifying genetic causes of NSHL, the goal of the current paper is to review epidemiology, etiology, and genetic causes of deafness in African populations worldwide with a focus on indigenous African populations. We will then discuss current and future strategies to discover the genes responsible for deafness in African populations worldwide. A productive initial approach may be to describe the specific genetic causes of hearing loss in indigenous African populations with low foreign genetic admixture. Populations in Northern Africa have significant genetic admixture with European and Middle Eastern populations (Henn et al., 2012); we, therefore, will focus our attention on findings from populations in Sub-Saharan African, an area, which, despite European colonization, has remained relatively genetically isolated.

To identify the most relevant publications regarding the etiology of hearing loss in sub-Saharan Africa, we used the keywords 'hearing loss, deafness, genetics, sub-Saharan, and Africa,' in both PubMed and Google Scholar. We later expanded the search terms to include keywords for specific syndromes and genetic mutations. These search terms yielded numerous publications from 1966 to the present, and all applicable case series, reviews, and genetic studies were included. We included only publications with specific mention of indigenous African populations or populations of indigenous African descent in this manuscript as other populations have distinctly different genetic backgrounds from our population of interest. A summary of these papers is included in Table 1. We excluded those studies that are not relevant to our topic such as those dealing with specific environmental etiologies, newborn hearing screening studies, and audiometry studies.

Our review includes 26 case reports, case series, reviews, and cross-sectional studies detailing the etiology of hearing loss for a total of roughly 10,500 patients with hearing loss of any cause, from Sub-Saharan Africa or of African descent. Collectively, 1.5\% of these subjects had syndromic deafness, while $29.8 \%$ had suspected non-syndromic genetic deafness, and $68.7 \%$ 
Table 1. Studies discussing hearing loss in populations of African descent, 1966 - Present

\begin{tabular}{|c|c|c|c|c|}
\hline Ethnic group & Sample description & $\begin{array}{l}\text { Gene or mutation } \\
\text { tested }\end{array}$ & Result & Reference \\
\hline African American & $\begin{array}{l}\text { Two parents and three children (aged } \\
\text { 5-9) with post-lingual progressive } \\
\text { autosomal dominant NSHL }\end{array}$ & MYOЗА & $\begin{array}{l}\text { p.Gly488Glu in MYO3A; novel interaction between } M Y O 3 A \\
\text { and } P C D H 15 .\end{array}$ & Grati et al., 2016 \\
\hline African American & $\begin{array}{l}23 \text { African American simplex cases } \\
\text { from New York }\end{array}$ & $\begin{array}{l}\text { GJB2, GJB6, } \\
\text { mtDNA }\end{array}$ & $\begin{array}{l}\text { GJB2 benign polymorphisms in two African Americans; no GJB6 or } \\
\text { mtDNA mutations. }\end{array}$ & Samanich et al., 2007 \\
\hline Angolan & Two dizygotic twins with KID syndrome & GJB2, GJB6 & $\begin{array}{l}\text { Two patients with a rare lethal form of KID are found to be } \\
\text { heterozygous for c.134G>A (p.Gly45Glu) mutation in GJB2 }\end{array}$ & Jonard et al., 2008 \\
\hline Bantu & Two brothers & $\mathrm{N} / \mathrm{A}$ & Case report of two brothers with Pendred syndrome & Levin, 1966 \\
\hline Brazilian & 100 African Brazilians & GJB2, g.3352delG & $1 / 100$ found to be heterozygous for g.3352delG & Oliveira et al., 2004 \\
\hline Cameroonian & $\begin{array}{l}70 \text { children with severe to profound pre- } \\
\text { lingual deafness }\end{array}$ & GJB2, MT-RNR1 & $\begin{array}{c}\text { GJB2 mutation p.Asn62Asn in two patients }(3.28 \%) ; M T-R N R 1 \\
\text { variants detected (m.1503G }>A \text {, m.1018G }>\mathrm{T}, \mathrm{m} .959 \mathrm{C}>\mathrm{T} \text {, and } \\
\mathrm{m} .1048 \mathrm{C}>\mathrm{T}) \text { and one novel variant }(\mathrm{m} .1462 \mathrm{G}>\mathrm{T})\end{array}$ & Trotta et al., 2010 \\
\hline Cameroonian & $\begin{array}{l}582 \text { subjects aged } 1-32 \text { with onset at } \\
<15 \text { years old. }\end{array}$ & $\mathrm{N} / \mathrm{A}$ & $\begin{array}{c}\text { Hearing loss is due to genetic (14.8\%), environmental (52.6\%), } \\
\text { unknown }(32.6 \%) \text { causes. Genetic causes include non-syndromic } \\
(86.1 \%) \text { and syndromic hearing loss }(13.9 \%) \text { with Waardenburg } \\
\text { syndrome representing } 7 \% \text { of all genetic cases. }\end{array}$ & $\begin{array}{l}\text { Wonkam, 2013; } \\
\text { Noubiap et al., } 2014\end{array}$ \\
\hline $\begin{array}{l}\text { Cameroonian and } \\
\text { South African }\end{array}$ & 205 black patients with NSHL & GJB2, GJB6, GJA1 & $\begin{array}{l}\text { No pathogenic mutations were detected in GJB2, GJB6, GJA1, or } \\
\text { GJB6-D3S1830. }\end{array}$ & Wonkam et al., 2015 \\
\hline $\begin{array}{l}\text { Cameroonian and } \\
\text { South African }\end{array}$ & 205 black patients with NSHL & GJB2 & No pathogenic mutations were found. & Bosch et al., 2014 \\
\hline Djiboutian & One six-year-old boy & $\mathrm{N} / \mathrm{A}$ & Case report of Leopard syndrome & Massoure et al., 2012 \\
\hline Gambian & $\begin{array}{l}259 \text { severe to profoundly deaf children } \\
\text { aged } 2-10 \text { years. }\end{array}$ & $N / A$ & $\begin{array}{l}\text { Postnatally acquired hearing loss (i.e. infection, } n=167) \text {, congenital } \\
\qquad(n=5) \text {, unknown }(n=81) \text {, other }(n=6)\end{array}$ & McPherson, 1985 \\
\hline Ghanaian & 21 deaf subjects from 11 families & GJB2 & All affected subjects homozygous for GJB2 mutation p.R143W. & Brobby et al., 1998 \\
\hline Ghanaian & $\begin{array}{l}365 \text { unrelated individuals aged } 6-10 \\
\text { years with profound NSHL. }\end{array}$ & GJB2, p.R143W & $\begin{array}{c}51 \text { individuals homozygous, } 4 \text { individuals heterozygous, } 4 \text { compound } \\
\text { heterozygous. }\end{array}$ & Hamelmann et al., 2001 \\
\hline Kenyan and Sudanese & $\begin{array}{l}589 \text { Sudanese }(n=162) \text { and Kenyan }(n \\
=406) \text { children with pre-lingual NSHL. }\end{array}$ & GJB2 & $\begin{array}{l}10 \text { novel variants identified: g.3318-6T>A, g.3318-15C>T, } \\
\text { g.3318-34C>T, g.3318-35T>G, g.3455_3460del, g.3512C >A } \\
\text { (p.Tyr65X), g.3395C>T (p.Thr26Thr), g.3503C >T (p.Asn62Asn), } \\
\text { g.3627A }>C \text { C (p.Arg104Arg) and g.3816C >A (p.Val167Met). }\end{array}$ & Gamelseed et al., 2004 \\
\hline Multiple & $\begin{array}{l}\text { Normal hearing individuals from } \\
\text { multiple regions including North } \\
\text { Africa/African Americans }\end{array}$ & GJB2, g.3352delG & $\begin{array}{l}\text { Identified in Jews of North African origin, but not in African } \\
\text { Americans. }\end{array}$ & Gasparini et al., 2000 \\
\hline
\end{tabular}




\begin{tabular}{|c|c|c|c|c|}
\hline Nigerian, Yoruba tribe & $\begin{array}{l}44 \text { individuals aged } 8 \text { months to } 45 \\
\text { years with NSHL }\end{array}$ & $\begin{array}{c}\text { GJB2, GJB6, MT- } \\
\text { RNR1 }\end{array}$ & No pathogenic mutations were found. & Lasisi et al., 2014 \\
\hline Nigerian & One three-day-old male child & $\mathrm{N} / \mathrm{A}$ & Case report of Goldenhar syndrome & Adeoye, 2002 \\
\hline North African & $\mathrm{N} / \mathrm{A}$ & 730,000 DNA sites & $\begin{array}{l}\text { History of migrations, involving at least five ancestral populations, } \\
\text { into North Africa. }\end{array}$ & Henn et al., 2012 \\
\hline $\begin{array}{l}\text { North American, } \\
\text { Mixed }\end{array}$ & $\begin{array}{l}\text { Survey including } 50 \text { African Americans } \\
\text { from hearing-impaired families }\end{array}$ & GJB2, GJB6 & $\begin{array}{c}\text { GJB2 mutations accounting for } 22.2 \% \text { of deafness across all } \\
\text { ethnicities. }\end{array}$ & Pandya et al., 2003 \\
\hline $\begin{array}{l}\text { South African and } \\
\text { Nigerian }\end{array}$ & $\begin{array}{l}342 \text { GJB2-negative deaf probands from } \\
\text { multiple countries }\end{array}$ & 180 genes & $\begin{array}{l}\text { Etiologic diagnostic rate for families from Nigeria and South Africa is } \\
4 \% \text {. No GJB2, GJB6, or mtDNA mutations were found. }\end{array}$ & Yan et al., 2016 \\
\hline $\begin{array}{l}\text { South African } \\
\text { (Limpopo) }\end{array}$ & 182 children aged $5-21$. & $\begin{array}{l}\text { GJB2, GJB6, MT- } \\
\text { RNR1 }\end{array}$ & No mutations in GJB2, GJB6-D13S1380, or mtDNA were found. & Kabahuma et al., 2011 \\
\hline South African & $\begin{array}{l}1 \text { family with } 18 \text { members, mixed } \\
\text { ancestry }\end{array}$ & $\begin{array}{l}\text { MT-RNR1, } \\
\mathrm{m} .1555 \mathrm{~A}>\mathrm{G}\end{array}$ & $\begin{array}{l}\text { The } M T-R N R 1 \mathrm{~m} .1555 \mathrm{~A}>\mathrm{G} \text { was homoplasmic in nine affected family } \\
\text { members following streptomycin exposure and wild-type in nine } \\
\text { normal hearing with no streptomycin exposure. }\end{array}$ & Gardner et al., 1997 \\
\hline South African & $\begin{array}{l}52 \text { black MDR-TB patients on } \\
\text { aminoglycosides with } 112 \text { black } \\
\text { controls }\end{array}$ & $M T-R N R 1$ & $\begin{array}{c}\text { One MDR-TB patient with m. } 827 \mathrm{~A}>\mathrm{G} \text { mutation. The } \mathrm{m} .1555 \mathrm{~A}>\mathrm{G} \\
\text { was found in } 0.9 \% \text { of black controls. }\end{array}$ & Human et al., 2010 \\
\hline South African & One fifteen-month-old female & $\mathrm{N} / \mathrm{A}$ & Case report of Goldenhar syndrome & $\begin{array}{l}\text { Naidoo and Stephen, } \\
1998\end{array}$ \\
\hline $\begin{array}{l}\text { South African - Sotho, } \\
\text { Zulu, Xhosa tribes }\end{array}$ & $\begin{array}{c}12 \text { indigenous and } 3 \text { mixed ancestry } \\
\text { with Usher; } 6 \text { with retinal degenerative } \\
\text { disease/hearing loss but no Usher } \\
\text { diagnosis. }\end{array}$ & $\begin{array}{l}\text { MYO7A, } \\
\text { c.6377delC }\end{array}$ & $\begin{array}{l}\text { Homozygous MYO7A mutation c. } 6377 \text { delC underlies } 43 \% \text { of USH } \\
\text { cases; } 60 \% \text { of these are Usher Type II. }\end{array}$ & Roberts et al., 2015 \\
\hline Southern African & 2410 profoundly deaf black children & $\mathrm{N} / \mathrm{A}$ & $\begin{array}{c}\text { Genetic syndromes (8\%), undifferentiated familial deafness (12\%), } \\
\text { acquired (25\%) and unknown (55\%). }\end{array}$ & Beighton et al., 1991 \\
\hline Southern African & $\begin{array}{l}264 \text { pediatric cochlear implant } \\
\text { recipients with hearing loss before } 5 \\
\text { years old. }\end{array}$ & $\mathrm{N} / \mathrm{A}$ & $\begin{array}{c}10 \% \text { of children }(n=23) \text { had a genetic syndrome (Waardenburg, } \\
\text { Ushers, Pierre Robin, Leopard). Of } 90 \text { children with Waardenburg } \\
\text { syndrome, } 33(2.6 \%) \text { were black. }\end{array}$ & Le Roux et al., 2015 \\
\hline Southern African & 1226 deaf black children & $\mathrm{N} / \mathrm{A}$ & $33(2.6 \%)$ black children with Waardenburg syndrome. & $\begin{array}{l}\text { Sellers and Beighton, } \\
1983\end{array}$ \\
\hline Sub-Saharan African & One child & N/A & Case report of KID syndrome & Barruet et al., 2011 \\
\hline Sub-Saharan African & $\mathrm{N} / \mathrm{A}$ & $\mathrm{N} / \mathrm{A}$ & $\begin{array}{l}\text { Review of causes of hearing loss including environmental, syndromic } \\
\text { and non-syndromic causes. }\end{array}$ & Lebeko et al., 2015 \\
\hline $\begin{array}{l}\text { Togolese (West } \\
\text { Africa) }\end{array}$ & 1 child of consanguineous marriage & $\mathrm{N} / \mathrm{A}$ & Case report of KID syndrome & Kombate et al., 2015 \\
\hline Ugandan & $\begin{array}{c}126 \text { simplex cases aged } 2-25 \text { years } \\
\text { with NSHL }\end{array}$ & GJB2, GJB6 & $\begin{array}{l}\text { One pathogenic variant in } G J B 2(c .208 C>G, p . P 70 A) \\
\text { three variants }(c .-22-12 C>T, C .-15 C>T, c .-6 T>A) \\
\text { two novel variants }(c .-23+12 G>A, c .-23+37 C>T)\end{array}$ & Javidnia et al., 2014 \\
\hline
\end{tabular}


either had acquired hearing loss or were unable to be determined based on thorough review of the article. In this review, we included 159 patients of African descent for whom an etiologic NSHL diagnosis is known. The geographic distribution included is primarily sub-Saharan Africa, defined as all African countries located south of the Sahara Desert, with most patients from Cameroon, Ghana, Kenya, Sudan, and South Africa. Several of the papers included in this review describe populations of African descent in North and South America, including cohorts from North America and Brazil, as well as North African subjects with Arab influences.

\section{Environmental causes of congenital deafness}

Congenital hearing loss may be environmental or genetic. In developed countries with modern prenatal care and vaccination, deafness occurs in 1 in 1000 births with genetic forms of hearing loss being the leading cause of congenital deafness. In developing countries, however, the rate of deafness is 3 in 1000 births, with environmental causes continuing to be the main contributor to congenital hearing loss. In developing countries of Sub-Saharan Africa with predominantly indigenous African populations, this rate of congenital deafness is higher, 6 per 1000 births in South Africa and 7 per 1000 births in Nigeria for example, suggesting a higher burden of environmental deafness in these populations (Lebeko et al., 2015). This can be attributed to multiple factors in the perinatal and early childhood periods including limited healthcare access, lack of vaccination, maternal infection and malnutrition during pregnancy, birth trauma, and perinatal infections such as bacterial meningitis. With the current low rate of neonatal hearing screening in Africa, the resultant hearing loss may only be diagnosed months or years later, confounding the classification of the hearing loss into congenital or acquired.

In a study among 582 deaf patients in Cameroon to determine etiology, a review of family history including pedigree drawing and identification of consanguinity, and a comprehensive retrospective chart review were performed. The results attributed the majority of cases (53\%) to environmental causes, $15 \%$ to genetic components, and the remaining $32 \%$ to unknown causes. Of those cases due to genetics, $13 \%$ were attributed to a syndromic form of hearing loss (Wonkam et al., 2013). 
Similar findings were seen in a study of 259 Gambian hearing impaired children aged from 2 to 10 years. Based on a detailed birth, medical, and family history, the study demonstrated that environmental exposure to illness accounted for the majority of cases, with nearly $32 \%$ attributed to meningitis or meningitis-like symptoms and an additional $25 \%$ to other common childhood illness (e.g., rubella, fever). Genetic factors contributed to a low $8 \%$ of the cases and for the remainder the etiologies were unknown (McPherson and Holborow, 1985).

However, both of these studies relied heavily on clinical history rather than medical testing, perhaps underestimating the number of cases due to genetic factors. This high rate of environmental deafness compounded with a lack of complete medical records has complicated the task of deciphering the genetic contribution to congenital hearing loss in African populations.

\section{The impact of cultural and social practices}

The reliance on traditional forms of healing and on traditional healers has at times delayed patients from seeking formal medical attention in a timely fashion. For example, seeking tribal medicine for a child with a fever due to meningitis will delay the administration of suitable antibiotics, leading to sequelae such as deafness.

Single parent homes and disruption of family structures due to migratory labor practices are both commonplace in many parts of sub-Saharan Africa. Children are then brought up by single mothers, grandparents or other relatives. While taking a medical history, valuable information may be unknown to the primary caregiver and therefore may be missed. On the other hand, the discouragement of close family mating and consanguineous mating among sub-Saharan populations protects against the clustering of defective genes in the population.

\section{Syndromic deafness}

Among cases of genetic or familial hearing loss, several syndromic conditions have been encountered in Sub-Saharan Africa. As early as 1977, Sellars and Beighton studied 499 deaf black children from three special schools for the deaf in Transkei, Ciskei, and the eastern Orange Free State of Southern Africa and identified 21 children aged 6 to 18 years with genetic syndromes. Based on clinical and otologic examinations, researchers identified Waardenburg ( $n$ 
$=13)$, vitiligo deafness $(n=2)$, treacher collins $(n=2)$, Hunters $(n=1)$, Crouzon's $(n=1)$, Pendred's $(n=1)$, and trichorhinophalangeal $(n=1)$ syndromes (Sellars, 1977). Additional reports of syndromic deafness in Sub-Saharan Africa include cases of Usher's, Pierre Robinson, and Leopard syndromes (le Roux et al., 2015). While these syndromes account for the majority of syndromic hearing loss cases in the developed world, they are infrequent causes of hearing loss in African populations and are not considered to be strong risk factors for hearing loss in these populations (Friderichs et al., 2012).

\subsection{Waardenburg syndrome (WS)}

Waardenburg syndrome is a group of genetic conditions that cause pigmentation changes in the hair, skin, and eyes, and has been noted as the most common cause of syndromic hearing loss in Sub-Saharan populations (Lebeko et al., 2015). However, it still only accounts for approximately 3\%-5\% of genetic cases (Beighton et al., 1991). In 1983, Sellers and Beighton evaluated 3006 school children and identified 90 (3.0\%) as having Waardenburg Syndrome. This study included 1226 indigenous African children, of whom 33 were affected (2.7\%) (Sellars and Beighton, 1983). Waardenburg Syndrome typically follows an autosomal dominant inheritance pattern; however, a number of de novo cases have been described in a Cameroonian cohort (Noubiap et al., 2014).

\subsection{Usher syndrome (USH)}

Usher syndrome is clinically characterized by hearing loss and retinitis pigmentosa. It has three clinical subtypes and is a common cause of combined hearing loss and blindness worldwide. To date, 11 genes have been associated with USH, with numerous autosomal recessive mutations reported in USH1C, MYO7A, and CDH23 (Lebeko et al., 2015). USH is less common in SubSaharan Africa, representing only 1\%-2\% of genetic cases; however, researchers recently described a rare c.6377delC (p.Pro2126Leufs*5) mutation in the MYO7A gene in two unrelated African individuals. Further analysis revealed that this is the causative mutation in 12 additional African individuals with hearing loss. This particular mutation has only been reported once before in a heterozygous Caucasian individual (Roberts et al., 2015).

\subsection{Pendred syndrome}


Pendred syndrome is a form of sensorineural hearing loss (SNHL) associated with thyroid goiter that accounts for $<1 \%$ of genetic causes of hearing loss in Sub-Saharan Africa (Beighton et al., 1991; Wonkam et al., 2013). There are rare case reports in the literature, with the first cases in Africa described by Levin and Glugman in 1966 in two South African Bantu brothers (Levin and Klugman, 1966).

Additionally, there have been case studies describing less frequently encountered syndromes (Lebeko et al., 2015). Two cases of Goldenhar, or oculo-auriculo-vertebral, syndrome have been described in a 3-day-old child in Nigeria (Adeoye, 2002) and a 15-month-old child in South Africa (Naidoo and Stephen, 1998). The genetics of this syndrome is not well understood, and its inheritance is believed to be multifactorial. Though only about 100 cases have been reported worldwide, several cases of keratitis-ichthyosis-de afness (KID) syndrome, defined by cornea, skin, and hearing abnormalities, have been described in Sub-Saharan Africa including Togo (Barruet et al., 2011; Kombate et al., 2015) and Cameroon. In Cameroon, two unrelated patients, ages 5 and 2, were found to have a sporadic p.Asp50Asn mutation in the GJB2 gene, previously described only in a single African patient from the Emirates (Wonkam et al., 2013). Additionally, a set of African monozygotic twins, one referred at birth and one at 3 months, have been described with a p.Gly45Glu (G45E) mutation in the GJB2 gene, coding for a lethal form of the disease within the first year of life (Jonard et al., 2008). The extremely rare Leopard syndrome, due to a defect in the protein tyrosine phosphatase non-receptor 11 gene (PTPN 11) on chromosome 12 , is characterized by abnormalities of the skin, heart, and ear and has been described in one 6-year-old Djiboutian boy (Massour e et al., 2012).

\section{Non-syndromic deafness}

Non-syndromic hearing impairment accounts for the majority of inherited hearing loss, approximately $70 \%$. In the US, autosomal-recessive inheritance is responsible for about $80 \%$ of cases of non-syndromic hearing impairment, while autosomal-dominant genes cause $20 \%$, and less than $2 \%$ of cases are caused by X-linked and mitochondrial genetic malfunctions. Comprehensive review of the relatively sparse literature of NSHL in populations of African descent shows 12 different pathogenic genes, including 34 different pathogenic or likely pathogenic mutations in 159 individuals with a confirmed etiology of genetic NSHL (Table 2). 
Table 2. Mutations associated with non-syndromic hearing loss in populations of African descent

\begin{tabular}{|c|c|c|c|c|c|c|c|}
\hline Mutation & Ethnic group & $\begin{array}{l}\text { Affected/sample } \\
\text { size }\end{array}$ & $\begin{array}{c}\text { Number of } \\
\text { pathogenic or } \\
\text { likely pathogenic } \\
\text { alleles }\end{array}$ & $\begin{array}{c}\text { Frequency of } \\
\text { mutated allele* }\end{array}$ & Variant classification & $\begin{array}{l}\text { Description of } \\
\text { hearing loss }\end{array}$ & Reference \\
\hline \multicolumn{8}{|c|}{ GJB2 $\left(n^{* *}=189\right)-$ gap junction in cochlea involved in ion recycling } \\
\hline \multirow{3}{*}{ g.3352delG (c.35delG) } & Kenyan/Sudanese & $5 / 589\left(\right.$ hom $\left.^{\#}\right)$ & 10 & 0.041 & \multirow{3}{*}{ Pathogenic, frameshift mutation } & Not discussed & $\begin{array}{l}\text { Gasmelseed } \\
\text { et al., } 2004\end{array}$ \\
\hline & African American & $7 / 50$ & 7 & 0.029 & & Not discussed & $\begin{array}{l}\text { Pandya et } \\
\text { al., } 2003\end{array}$ \\
\hline & Afro-Brazilian & $1 / 100$ & 1 & 0.004 & & $\begin{array}{l}\text { Carrier only } \\
\text { (frequency = } 1 \%, q \\
=0.005 \text { ); } \mathrm{HL} \text { not } \\
\text { assessed. }\end{array}$ & $\begin{array}{l}\text { Oliveira et } \\
\text { al., } 2004\end{array}$ \\
\hline $\begin{array}{c}\text { g.3455_3460del } \\
\text { (c.138_143del, } \\
\text { p.Asp46_Gln48delinsGlu) }\end{array}$ & Kenyan/Sudanese & $1 / 589$ (het $\left.{ }^{\# \#}\right)$ & 1 & 0.004 & $\begin{array}{l}\text { Pathogenic, novel frameshift } \\
\text { mutation }\end{array}$ & Not discussed & $\begin{array}{l}\text { Gasmelseed } \\
\text { et al., } 2004\end{array}$ \\
\hline $\begin{array}{c}\text { g. } 3512 C>A(c .195 C>A, \\
\text { p.Tyr65X) }\end{array}$ & Kenyan/Sudanese & $1 / 589$ (het) & 1 & 0.004 & Pathogenic, novel stop codon & Not discussed & $\begin{array}{l}\text { Gasmelseed } \\
\text { et al., } 2004\end{array}$ \\
\hline c.208C>G (p.Pro70Ala) & Ugandan & $1 / 115$ & 1 & 0.004 & Pathogenic & $\begin{array}{l}\text { Bilateral, severe to } \\
\text { profound, pre- } \\
\text { lingual HL }\end{array}$ & $\begin{array}{l}\text { Javidnia et } \\
\text { al., } 2014\end{array}$ \\
\hline $\begin{array}{c}\text { g.3741_2743delTTC } \\
\text { (p.F142del) }\end{array}$ & Cameroon & $1 / 205$ & 1 & 0.004 & Pathogenic & Not discussed & $\begin{array}{l}\text { Bosch et al., } \\
2014\end{array}$ \\
\hline \multirow{3}{*}{$\begin{array}{c}\text { g. } 3744 C>T(c .427 C>T \\
\text { p.R143W) }\end{array}$} & \multirow[b]{2}{*}{ Ghana } & 21/21 (hom) & 42 & 0.174 & \multirow{3}{*}{$\begin{array}{c}\text { Pathogenic, } \\
\text { compound het (p.R143W/35insG; } \\
\text { p/R143W/I203K; p.R143W/L79P; } \\
\text { p.R143W/L214P) }\end{array}$} & \multirow{3}{*}{$\begin{array}{l}\text { Bilateral, severe to } \\
\text { profound, } \\
\text { congenital, } \\
\text { nonsyndromic, } \\
\text { sensorineural HL }\end{array}$} & $\begin{array}{c}\text { Brobby et al. } \\
1998\end{array}$ \\
\hline & & 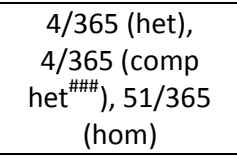 & 110 & 0.456 & & & $\begin{array}{l}\text { Hamelmann } \\
\text { et al., } 2001\end{array}$ \\
\hline & African American & $1 / 50$ & 1 & 0.004 & & & $\begin{array}{l}\text { Pandya et } \\
\text { al., } 2003\end{array}$ \\
\hline $\begin{array}{l}\text { g. } 3795 \mathrm{G}>\mathrm{A} \text { (c. } 478 \mathrm{G}>\mathrm{A}, \\
\text { p.Gly160Ser) }\end{array}$ & Kenyan/Sudanese & $1 / 589$ (het) & 1 & 0.004 & $\begin{array}{c}\text { Pathogenic, nonsynonymous } \\
\text { mutation }\end{array}$ & Not discussed & $\begin{array}{l}\text { Gasmelseed } \\
\text { et al., } 2004 \\
\end{array}$ \\
\hline \multirow{2}{*}{$\begin{array}{l}\text { g.3816C }>\text { A or g.3816G }>A \\
\text { (p.Val167Met) }\end{array}$} & Kenyan/Sudanese & 4/589 (het) & 4 & 0.017 & $\begin{array}{l}\text { Pathogenic, novel nonsynonymous } \\
\text { mutation }\end{array}$ & Not discussed & $\begin{array}{l}\text { Gasmelseed } \\
\text { et al., } 2004\end{array}$ \\
\hline & Cameroon & $1 / 205$ (het) & 1 & 0.004 & Pathogenic & Not discussed & $\begin{array}{c}\text { Bosch et al., } \\
2014\end{array}$ \\
\hline $\begin{array}{c}\text { g.3850T }>C \text { (c.533T }>C \\
\text { p.Val178Ala) }\end{array}$ & Ghana & 2/365 (hom) & 4 & 0.017 & $\begin{array}{c}\text { Pathogenic, novel missense } \\
\text { mutation, recessive }\end{array}$ & \multirow{3}{*}{$\begin{array}{l}\text { Bilateral, profound, } \\
\text { nonsyndromic, } \\
\text { sensorineural HL in } \\
\text { childhood. } \\
\text { Unspecified onset } \\
\text { or progression. }\end{array}$} & \multirow{3}{*}{$\begin{array}{l}\text { Hamelmann } \\
\text { et al., } 2001\end{array}$} \\
\hline $\begin{array}{c}\text { g.3868G }>\text { A (c.551G }>A, \\
\text { p.Arg184GIn) }\end{array}$ & Ghana & $1 / 365$ (het) & 1 & 0.004 & $\begin{array}{l}\text { Pathogenic, novel missense } \\
\text { mutation, dominant }\end{array}$ & & \\
\hline $\begin{array}{c}\text { g.3906G }>\mathrm{T} \text { (c.589G }>\mathrm{T}, \\
\text { p.Ala197Ser) }\end{array}$ & Ghana & $1 / 365$ (het) & 1 & 0.004 & $\begin{array}{l}\text { Pathogenic, novel missense } \\
\text { mutation }\end{array}$ & & \\
\hline
\end{tabular}




\begin{tabular}{|c|c|c|c|c|c|c|c|}
\hline $\begin{array}{c}\text { g.3426G }>\text { A (c.109G }>A, \\
\text { p.Val37lle) }\end{array}$ & Kenyan/Sudanese & $1 / 589$ (het) & 1 & 0.004 & Likely pathogenic & Not discussed & \multirow{2}{*}{$\begin{array}{l}\text { Gasmelseed } \\
\text { et al., } 2004\end{array}$} \\
\hline $\begin{array}{l}\text { g.3697G }>\text { A (c.380G }>A, \\
\text { p.Arg127His) }\end{array}$ & Kenyan/Sudanese & $1 / 589$ (het) & 1 & 0.004 & $\begin{array}{l}\text { Likely pathogenic, nonsynonymous } \\
\text { mutation }\end{array}$ & Not discussed & \\
\hline \multicolumn{8}{|c|}{ MARVELD2 $(n=2)$ - establishing epithelial barrier at tight junctions in organ of Corti } \\
\hline c.1555-1G>A (splice) & $\begin{array}{c}\text { Limpopo Province, } \\
\text { South Africa } \\
\end{array}$ & $1 / 91$ & 2 & 0.008 & Novel, likely pathogenic & Not discussed & $\begin{array}{c}\text { Yan et al., } \\
2016\end{array}$ \\
\hline \multicolumn{8}{|c|}{ MYO3a $(n=4)$ - autosomal dominant mutation affecting ATPase of motor domain in inner ear stereocilia } \\
\hline $\begin{array}{l}\text { rs145970949:G>A } \\
\text { (p.Gly488Glu) }\end{array}$ & African American & $4 / 4$ & 4 & 0.017 & Pathogenic & $\begin{array}{l}\text { Bilateral, } \\
\text { progressive, post- } \\
\text { lingual, } \\
\text { sensorineural HL }\end{array}$ & $\begin{array}{l}\text { Grati et al., } \\
2016\end{array}$ \\
\hline \multicolumn{8}{|c|}{ MYO6 $(n=2)$ - unconventional myosin aids in intracellular transport } \\
\hline $\begin{array}{c}\text { c.1477_1487delCAAGAACTCTA } \\
\text { (p.Q493Sfs*8) }\end{array}$ & $\begin{array}{l}\text { Yoruba tribe } \\
\text { (Ibadan, Nigeria) }\end{array}$ & $1 / 90$ & 2 & 0.008 & Novel, pathogenic & $\begin{array}{l}\text { Mild to profound, } \\
\text { congenital or pre- } \\
\text { lingual, } \\
\text { nonsyndromic HL }\end{array}$ & $\begin{array}{l}\text { Yan et al., } \\
2016\end{array}$ \\
\hline \multicolumn{8}{|c|}{ MYO7A $(n=7)$ - unconventional myosin aids in intracellular transport } \\
\hline c.6375delC (p.P2126Lfs*5) & $\begin{array}{l}\text { Limpopo Province, } \\
\text { South Africa }\end{array}$ & $1 / 91$ & 1 & 0.004 & Pathogenic & \multirow{7}{*}{$\begin{array}{c}\text { Mild to profound, } \\
\text { congenital or pre- } \\
\text { lingual } \\
\text { nonsyndromic HL }\end{array}$} & \multirow{7}{*}{$\begin{array}{l}\text { Yan et al., } \\
2016\end{array}$} \\
\hline c.1118G>A (p.R373H) & $\begin{array}{l}\text { Limpopo Province, } \\
\text { South Africa }\end{array}$ & $1 / 91$ & 1 & 0.004 & likely pathogenic & & \\
\hline c.1142C>T (p.T381M) & $\begin{array}{l}\text { Limpopo Province, } \\
\text { South Africa }\end{array}$ & $1 / 91$ & 1 & 0.004 & likely pathogenic & & \\
\hline c. $1554+7 C>T$ (splice) & $\begin{array}{l}\text { Limpopo Province, } \\
\text { South Africa }\end{array}$ & $1 / 91$ & 1 & 0.004 & Likely pathogenic & & \\
\hline c. $5326+7 G>A$ (splice) & $\begin{array}{l}\text { Limpopo Province, } \\
\text { South Africa }\end{array}$ & $1 / 91$ & 1 & 0.004 & Likely pathogenic & & \\
\hline c.287C>T (p.T96M) & $\begin{array}{c}\text { Yoruba tribe } \\
\text { (Ibadan, Nigeria) }\end{array}$ & $1 / 90$ & 1 & 0.004 & Novel, likely pathogenic & & \\
\hline c. $1708 \mathrm{C}>\mathrm{T}\left(\mathrm{p} . \mathrm{R} 570^{*}\right)$ & $\begin{array}{c}\text { Yoruba tribe } \\
\text { (Ibadan, Nigeria) }\end{array}$ & $1 / 90$ & 1 & 0.004 & Novel, pathogenic & & \\
\hline \multicolumn{8}{|c|}{ POU3F4 $(n=1)$ - transcription factor that regulates proliferation of neural stem cells } \\
\hline c.986G>C (p.R329P) & $\begin{array}{l}\text { Limpopo Province, } \\
\text { South Africa }\end{array}$ & $1 / 91$ & 1 & 0.004 & Likely pathogenic, hemizygous & $\begin{array}{l}\text { Mild to profound, } \\
\text { congenital or pre- } \\
\text { lingual, } \\
\text { nonsyndromic, HL }\end{array}$ & $\begin{array}{l}\text { Yan et al., } \\
2016\end{array}$ \\
\hline \multicolumn{8}{|l|}{ SIX1 $(n=1)$ - transcription factor } \\
\hline c.373G>A (p.G125L) & $\begin{array}{l}\text { Limpopo Province, } \\
\text { South Africa }\end{array}$ & $1 / 91$ & 1 & 0.004 & Likely pathogenic & $\begin{array}{l}\text { Mild to profound, } \\
\text { congenital or pre- } \\
\text { lingual, } \\
\text { nonsyndromic HL }\end{array}$ & $\begin{array}{l}\text { Yan et al., } \\
2016\end{array}$ \\
\hline
\end{tabular}




\begin{tabular}{|c|c|c|c|c|c|c|c|}
\hline \multicolumn{8}{|c|}{ SLC26A4 $(n=4)$ - tansporting chloride and iodine to maintain pH of endolymph } \\
\hline c.737delA (p.N246Tfs*43) & $\begin{array}{c}\text { Yoruba tribe } \\
\text { (Ibadan, Nigeria) }\end{array}$ & $1 / 90$ & 2 & 0.008 & Novel, pathogenic & \multirow{3}{*}{$\begin{array}{l}\text { Mild to profound, } \\
\text { congenital or pre- } \\
\text { lingual, } \\
\text { nonsyndromic HL }\end{array}$} & \multirow{3}{*}{$\begin{array}{l}\text { Yan et al., } \\
2016\end{array}$} \\
\hline c. $164+1 G>C$ (splice) & $\begin{array}{c}\text { Yoruba tribe } \\
\text { (Ibadan, Nigeria) }\end{array}$ & $1 / 90$ & 1 & 0.004 & Novel, pathogenic, splice & & \\
\hline$c .2171 \mathrm{~A}>\mathrm{T}(\mathrm{p} . \mathrm{D} 724 \mathrm{~V})$ & $\begin{array}{c}\text { Yoruba tribe } \\
\text { (Ibadan, Nigeria) }\end{array}$ & $1 / 90$ & 1 & 0.004 & Novel, likely pathogenic & & \\
\hline \multicolumn{8}{|c|}{ TRIOBP $(n=2)$ - actin binding protein involved in stabilization } \\
\hline c.572delC (p.P191Rfs*50) & $\begin{array}{l}\text { Limpopo Province, } \\
\text { South Africa }\end{array}$ & $1 / 91$ & 1 & 0.004 & Novel, likely pathogenic & \multirow{2}{*}{$\begin{array}{l}\text { Mild to profound, } \\
\text { congenital or pre- } \\
\text { lingual, } \\
\text { nonsyndromic HL }\end{array}$} & \multirow{2}{*}{$\begin{array}{l}\text { Yan et al., } \\
2016\end{array}$} \\
\hline $\begin{array}{c}\text { c.3510_3513dupTGCA } \\
\text { (p.P1172Cfs*13) }\end{array}$ & $\begin{array}{c}\text { Limpopo Province, } \\
\text { South Africa }\end{array}$ & $1 / 91$ & 1 & 0.004 & Novel, likely pathogenic & & \\
\hline \multicolumn{8}{|c|}{ MT-RNR1 (Mitochondrial) ( $n=27$ ) - predisposing to aminoglycoside ototoxicity } \\
\hline \multirow{2}{*}{ m.1555A>G } & \multirow{2}{*}{ Black South African } & $1 / 115$ & 1 & 0.004 & pathogenic & & $\begin{array}{l}\text { Human et al., } \\
2010\end{array}$ \\
\hline & & $18 / 18$ & 18 & 0.075 & pathogenic, homoplasmic & \multirow{2}{*}{$\begin{array}{l}\text { Aminoglycoside- } \\
\text { induced, bilateral }\end{array}$} & $\begin{array}{c}\text { Gardner et } \\
\text { al., } 1997\end{array}$ \\
\hline 961 delT+insC(n) & Black South African & $8 / 115$ & 8 & 0.033 & pathogenic & & $\begin{array}{l}\text { Human et al., } \\
2010\end{array}$ \\
\hline \multicolumn{8}{|c|}{ MT-ND3 (Mitochondrial) $(n=1)$ - encoding an NADH dehydrogenase involved in mitochondrial respiratory chain } \\
\hline m.10114T>C (p.lle19Thr) & Black South African & $1 / 115$ & 1 & 0.004 & Likely pathogenic & $\begin{array}{l}\text { Aminoglycoside- } \\
\text { induced }\end{array}$ & $\begin{array}{l}\text { Human et al., } \\
2010\end{array}$ \\
\hline \multicolumn{8}{|c|}{ MT-CYB (Mitochondrial) $(n=1)$ - encoding the cytochrome B protein involved in mitochondrial respiratory chain } \\
\hline m.15312T>C (p.lle18ThrT) & Black South African & $1 / 115$ & 1 & 0.004 & Likely pathogenic & $\begin{array}{l}\text { Aminoglycoside- } \\
\text { induced }\end{array}$ & $\begin{array}{l}\text { Human et al., } \\
2010\end{array}$ \\
\hline
\end{tabular}

*The mutation frequency is calculated based on this review of the literature. It is not a reported value from the original publications. ${ }^{* *} n=$ number of subjects with a mutation in the gene of interest
identified in review of the literature. ${ }^{\#}$ hom, homogeneous mutation; ${ }^{\# \#}$ het, heterogeneous mutation; ${ }^{\# \#}$ comp het, composite heterozygous mutation; HL, hearing loss. 


\subsection{GJB2}

Mutations of GJB2 are the most common cause of non-syndromic genetic deafness worldwide in non-African populations. Specific mutations are associated with specific populations: c.35delG in Europeans, c.167delT in Ashkenazi Jews, c.235delC in East Asians. In contrast, the few studies available suggest that $G J B 2$ is not a major cause of deafness in most African populations studied to date.

With the notable exception of Ghana (Chan and Chang, 2014), GJB2 has not been found to be a prominent genetic cause of hearing loss in sub-Saharan Africa. We have previously shown that none of the reported deafness-causing mutations in GJB2 nor any novel pathogenic mutations in the coding region were detected in an indigenous African population of the Limpopo Province of South Africa. The GJB6-D13S1830 deletion and the mitochondrial mutations were also not observed in this group (Kabahuma et al., 2011). GJB2 mutations were also absent among deaf probands from the Yoruba tribe residing in Ibadan, a suburban city in Nigeria (Lasisi et al., 2014). Similarly, an analysis of a large cohort of Ugandan deaf patients identified none of the common GJB2 deletions (Javidnia et al., 2014). Despite low rates of common GJB2 mutations in the Ugandan population, complete sequencing of 115 of the 126 individuals revealed one pathogenic variant in GJB2 (c.208C>G; p.Pro70Ala) (Javidnia et al., 2014). Analysis of the coding region of the GJB2 gene in 205 Cameroonian and Xhosa South Africans with congenital, non-syndromic deafness, also revealed low frequencies of common mutations but identified two monoallelic pathogenic mutations (p.F142del and p.V167M) in two unrelated Cameroonian participants (Bosch et al., 2014).

Most African populations do not show a high prevalence of GJB2 mutations. However, there is one specific GJB2 mutation, p.R143W (c.427C>T), with a relatively high prevalence in the Ghanaian population of the Adamorobe village, an inbred community (Hamelmann et al., 2001). These individuals presented with severe to profound bilateral congenital SNHL. Secondly, other GJB2 variants have been identified in $12.7 \%$ and $6.5 \%$ of Kenyan and Sudanese deaf persons, respectively. Collectively, the population's hearing loss is described as bilateral, sensorineural, non-syndromic, pre-lingual, and of severe to profou nd severity; hearing characteristics of 
specific variants are not described. Variants found include p.Tyr65X, p.Val167Met, c.35delG, p.Val37Ile, p.Val153Ile, p.Gly160Ser (Gasmelseed et al., 2004). It is noted that, in this study, there is no description of the population characteristics of the study group. The northern parts of Kenya bordering onto Sudan and Somalia are inhabited by individuals of Arab and Somali descent who migrated from the north. As such, this population group is not of clear African genetic makeup and may reflect a genetic admixture from Arabic populations further north.

We have previously reported that none of the 182 deaf African individuals from the Limpopo Province of South Africa carried any of the known disease causing mutations of GJB2, including c.35delG, or any other potentially pathogenic GJB2 mutations. There was, however, a high frequency of two GJB2 variants, C>T at position g.3318-3315 and C>T at p osition g.33183334 , which occurred in $21.4 \%$ and $46.2 \%$ of the deaf cohort respectively, and in $35 \%$ and $42.6 \%$ of a normal hearing control group, respectively, suggesting that these are common nonpathogenic polymorphisms (Kabahuma et al., 2011). These variants were also found with high frequency in populations from Cameroon, Uganda, Kenya, and Sudan, supporting their role as benign polymorphisms (Gasmelseed et al., 2004; Bosch et al., 2014; Javidnia et al., 2014).

Interestingly, the c.35delG mutation, common in Europeans, has been identified in 5/139 Sudanese deaf children and 1/100 Afro-Brazilians. In both cases, it has been suggested that the presence of this mutation is from genetic admixture with European populations rather than inherent in each population (Gasparini et al., 2000; Gasmelseed et al., 2004).

The c.35delG mutation is also rare among African American populations. Gaparini et al. (2000) assessed the carrier frequency of the c.35delG mutation in various populations, including 190 African Americans, and did not identify any carriers in this cohort. Another study examined 173 non-deaf African Americans for the c.35delG variant and 171 non-deaf African Americans for the $167 \mathrm{delT}$ variant and did not identify any carriers for either, suggesting that these alleles are of very low frequency (Morell et al., 1998).

One study identified GJB2 pathologic variants in $4 \%$ of 50 African American deaf patients, as compared to $26 \%$ of Caucasians and $11 \%$ of Hispanics in the same study, with c.35delG as the 
most common mutation in all ethnicities (Pandya et al., 2003). However, most deafness-causing genes in African individuals within the United States have yet to be identified.

Overall, more than 30 variants in the GJB2 gene have been described in deaf patients of African descent. Approximately 13 are thought to be pathogenic or likely pathogenic. These mutations along with their frequencies, if available, are listed in Table 2. Among them, $78 \%$ of all pathogenic or likely pathogenic NSHL mutations in populations of African descent included in this review are found on GJB2. However, much of this contribution is from the Ghanaian population alone. If Ghana is excluded, GJB2 mutations comprise only $37.3 \%$ of NSHL mutations in this review, with most studied populations of African descent having a complete absence of pathogenic GJB2 mutations.

\subsection{GJB6}

The most common mutation in GJB6 is the 342-kb GJB6-D13S1830 deletion, which causes NSHL when homozygous, or when present on the opposite allele of a GJB2 mutation. The GJB6-D13S1830 mutation, which is most frequent in Spain, France, the United Kingdom, Israel and Brazil (5.9\% $-9.7 \%$ of all DFNB1 alleles), is les s frequent in the USA, Belgium and Australia (1.3\%-4.5\% of all DFNB1 alleles), and ver y rare in Southern Italy (Del Castillo et al., 2003). In Northern Italy, frequencies are similar to those of other European countries.

Studies among African populations reported that pathologic GJB6 mutations have been widely screened but not identified. Specifically, they were found to be absent in African populations within South Africa (Kabahuma et al., 2011), Nigeria (Lasisi et al., 2014), Cameroon (Bosch et al., 2014), Brazil (Batissoco et al., 2009) and the United States (Pandya et al., 2003; Samanich et al., 2007).

\subsection{MTRNR1 (mitochondrial 12S ribosomal RNA)}

Mitochondrial DNA (mtDNA) mutations have been associated with non-syndromic and aminoglycoside-induced hearing loss. Mutations in MTRNRl gene, m.1555A>G, m.961delT/insC, m.961T>G, m.1095T>C, and m.1494C>T, have been found in some patients with aminoglycoside-induced hearing loss or hereditary non-syndromic NSHL. Among these, the 
commonest predisposing mutation is $\mathrm{m} .1555 \mathrm{~A}>\mathrm{G}$. This mutation has been detected in low frequency among African populations, including 18 family members of mixed ancestry in South Africa where nine of these family members had profound bilateral post-lingual hearing loss following aminoglycoside use, while the remaining nine were found to be carriers of the mutation but had not received aminoglycosides (Gardner et al., 1997). Human et al. (2010) later conducted a study that included 115 MDR-TB (multi-d rug resistant tuberculosis) patients all on aminoglycosides and 439 controls representative of the main ethnic groups in South Africa. Data analysis revealed the presence of homoplasmic mutations in controls $(\mathrm{m} .1555 \mathrm{~A}>\mathrm{G}$ in $0.9 \%$ of Black controls and $\mathrm{m} .827 \mathrm{~A}>\mathrm{G}$ in $1.1 \%$ of Afrikaner controls), suggesting that a significant proportion of the South African population is genetically predisposed to developing aminoglycoside-induced hearing loss. The 961 delT+insC $(n)$ (7.1\% of Black controls) and m.961T $>\mathrm{G}$ (2.9\% of Afrikaner controls) variants were found at frequencies ranging from $1.1 \%$ to 7.1\%. However, the incidence of ototoxicity in the MDR-TB patients harboring these mutations is not discussed in the review.

In those black patients for whom aminoglycoside induced ototoxicity was confirmed, researchers identified several novel variants in the MT-ND3 and $M T-C Y B$ genes including two likely pathogenic mutations m.10114T $>\mathrm{C}$ (I19T) and m.15312T $>\mathrm{C}$ (I189T) and three benign variants m.10128C >A (L24M), m.11318T >C (S187P), and m.15735C > T (A330V) (Human et al., 2010). Although m.10114T $>\mathrm{C}$ and m.10128C $>\mathrm{A}$ have been described in a South African pediatric population with neuromuscular mitochondrial respiratory chain disease, neither of these variants have otherwise been implicated in hearing loss (van der Walt et al., 2012).

Among 78 children with severe to profound prelingual deafness from Cameroon, researchers identified six mitochondrial variants including four known polymorphisms of the MTRNRl gene in the African population (m.1503G $>$ A, m.1018G $>\mathrm{T}, \mathrm{m} .959 \mathrm{C}>\mathrm{T}$, and m.1048C $>\mathrm{T}$ ) and one novel variant $(\mathrm{m} .1462 \mathrm{G}>\mathrm{T})$. This novel variant was also identified in deaf patients from two additional studies, suggesting a pathologic role in hearing loss (Trotta et al., 2011). 
Overall, mutations on MTRNR1 account for $11.2 \%$ of NSHL in populations of African descent included in this review, with the m.1555A $>\mathrm{G}$ mutation comprising $70 \%$ of these mutations (7.8\% of mutations in this study).

\subsection{MYO3A}

Several recessive, loss of function mutations in $M Y O 3 A$ causing hearing loss have been described in populations worldwide. Although mutations in this gene have not been described in indigenous African populations, researchers recently reported a dominant mutation responsible for a new form of NSHL in an African American family. Grati et al. (2016) performed exome sequencing on five African American family members with post-lingual, progressive, NSHL. Mutational analysis revealed a single novel variant, p.Gly488Glu, in the MYO3A gene (Grati et al., 2016). MYO3A is responsible for $1.7 \%$ of mutations in populations of African descent included in this review.

\section{Application of next-generation sequencing (NGS) in non-syndromic hearing loss}

NGS is rapidly expanding the knowledge of non-syndromic genetic deafness, particularly in previously under-studied populations. In use since the late 1990s, NGS encompasses several techniques of genome sequencing that produce thousands or millions of parallel and overlapping DNA sequences that allows for rapid and relatively inexpensive analysis of large segments of DNA.

As part of a recent multi-ethnic genetic deafness study, two deaf indigenous GJB2-negative subSaharan African populations were tested for genetic deafness using an NGS custom capture panel (MiamiOtoGenes, USA) (Yan et al., 2016). The study included 91 indigenous deaf persons from the Limpopo province of South Africa and 90 from the Yoruba tribe in Ibadan, Nigeria. Tunisia, a north African country, was also included in their study but will not be included in this discussion as the ethnic admixture in Tunisia is significantly higher given its European and Arabic genetic contribution.

The authors detected an etiologic genetic deafness diagnosis in $4 \%$ of families from both South Africa and Nigeria. This is a relatively low rate compared to non-Sub-Saharan African 
populations (28\%). This may be due in part to the larger number of simplex cases (one family member affected) versus the multiplex cases (in which multiple members of the family are affected) among the South African and Nigerian cohorts in comparison to the other ethnic groups. This study further reported solved rates of $7 \%$ for simplex families compared to $25 \%$ for multiplex families overall, suggesting that a positive family history of deafness may be an important indicator for a genetic etiology.

This study also detected a high number of variants of unknown significance (VUS), especially among the sub-Saharan African cohorts. South Africa has the highest number of VUS (23), followed closely by Nigeria (18). The main difference is seen among the simplex families, with 15 and 12 for South Africa and Nigeria, respectively. As a comparison, ethnic cohorts in Tunisia, Turkey, Iran, and India show no VUS, with only two VUS identified in USA and Guatemalan cohorts.

It is, however, the unsolved numbers that reflect the true picture of the state of genetic deafness research among different ethnic groups. The data coming out of sub-Saharan African populations show a high number of unsolved variants compared to the non-sub-Saharan cohorts. The South African cohort reported a total of 64 unsolved variants (53 simplex, 11 multiplex), while Nigeria reported 68 unsolved variants (51 simplex and 17 multiplex). Compared to the USA which had almost equal numbers of simplex and multiplex unsolved variants (18 and 17 respectively), to Tunisia with 20 unsolved variants ( 0 simplex and 20 multiplex), or to Guatemala with four unsolved variants (two simplex, two multiplex), this is a significant finding.

Two issues must be clarified if one is to make logical conclusions from this data. One, all the deaf probands were recruited by experienced and highly trained otolaryngologists who are based in those countries (South Africa and Nigeria), and who understand both the cultures and the languages of the local people. Second, based on the foregoing, it can be accepted that all these deaf individuals were correctly assessed and that environmental causes for the hearing loss were excluded, leaving only genetic causes for the hearing loss as reported. From these observations, it therefore becomes apparent that the high number of unsolved cases are all due to a genetic 
cause whose genes and mutations have either not yet been identified or fall outside of the gene pool included in the gene panel used in this study.

To support this conclusion, it is notable that the unsolved cases from the countries that practice consanguineous mating or where inbreeding is prevalent, such as Tunisia, India, Iran, and Turkey, were found mainly in the multiplex families. The sub-Saharan communities in South Africa and Nigeria, where the deaf probands were recruited, discourage consanguineous mating. When one considers that large endogamous populations were instrumental in mapping genes for NSHL (Keats and Berlin, 1999), and the extreme heterogeneity of genetic hearing loss, these findings are to be expected. In the sub-Saharan populations, natural spread of mutations and variations is expected, leading to a larger number of simplex cases compared to multiplex cases. A high number of de novo mutations are therefore to be expected. The reverse holds for inbred communities where clustering of mutations occurs due to inbreeding and consanguineous mating. Recessive genetic defects will cluster in the latter communities, as exemplified by the founder effect.

Despite these limitations, this was the first study to successfully identify several likely pathogenic deafness-causing variants in sub-Saharan populations (Yan et al., 2016). Additionally, several other genes found to have VUS in these South African and Nigerian populations will require further investigation.

\section{Future work}

Deafness research in Africa has long lagged behind the developed world due to lack of diligent medical records, poor access to health care, limited infrastructure, low number of skilled workers along with the outflow of skilled researchers to developed countries, funding, and limited access to high-impact journals for relatively lesser-known African researchers. Additionally, the environmental impact on deafness and the widespread avoidance of consanguinity in African societies, further minimize the genetic contributions to disease (McPherson and Swart, 1997) and increase the burden of genetic data needed for pathologic mutation identification. However, genetic deafness research in populations of African descent has advanced tremendously over the 
last two decades with the advent of NGS and the increasing level of collaboration between African universities with genetic research centers abroad.

South Africa is addressing the issue of poor continuity of patient care in Africa as well as the suboptimal medical records by the development of a unique healthcare identifier system, currently in its pilot phase. In this system, the patient will retain a unique identifier throughout life and his or her medical records are accessible in all public hospitals nationally. The anticipated effects in medical management, patient tracing, and clinical research are expected to be transforming.

Common variants responsible for genetic deafness in populations are not common in individuals of African descent; in fact, some authors argue that there is no clinical utility in screening for GJB2, GJB6, or GJA1 in black Africans (Wonkam et al., 2015). Recent work by Yan et al (2016) showed promising use of a large screening deafness gene panel (MiamiOtoGenes) for detecting rare or novel mutations in a rapid and cost-effective manner. In patients shown to be negative for GJB2, GJB6, and mitochondrial mutations, NGS with the MiamiOtoGenes panel revealed several candidate deafness genes for the first time in sub-Saharan African populations (Nigeria and Limpopo, South Africa).

In those patients for whom a diagnosis is still not obtained, whole-exome sequencing or even whole-genome sequencing is then the next step. This type of sequential genetic screening approach will become increasingly important for both research and clinical applications. Much work remains to elucidate the genetic causes of hearing loss in populations of African descent worldwide, but with the development of NGS and efficient deafness gene-screening protocols, the present and future of genetic deafness research has never looked brighter.

\section{Conclusion}

Globally, acquired causes of hearing loss remain the predominant etiology of hearing loss in patients of African descent. With improved preventative care, including vaccination and perinatal care, genetic causes of hearing loss will take on a larger proportion of the hearing loss burden in this population. Syndromic hearing loss in Africa is primarily caused by Pendred, 
Waardenburg, and Usher Syndromes. Specific genetic causes of NSHL have been elusive in populations of African descent. Review of the global literature shows 12 genes and 34 mutations known to be responsible for NSHL in these populations, with most individuals having bilateral, severe to profound hearing loss of prelingual onset. GJB2 remains a relatively uncommon contributor to NSHL in most of these populations, with the exception of Ghana. In at-risk populations of African descent, screening for mitochondrial mutations predisposing to aminoglycoside toxicity may prevent hearing loss. The remainder of identified genes causing NSHL in these populations are all relatively rare but may warrant incorporation into populationspecific gene panels (MYO7A, MYO3A, SLC26A4, MARVELD2, MYO6, POU3F4, SIX1, and TRIOBP). With recent advancement in sequencing technologies like NGS and populationspecific gene panels, we are poised for rapid advance in diagnosis of genetic hearing loss in populations of African descent.

\section{Acknowledgments}

This study was supported by grants from the National Institutes of Health/National Institute on Deafness and Other Communication Disorders to Xuezhong Liu (Nos., R01 DC05575, R01 DC01246, 2P50DC000422-Sub-Project 6432, and R01 DC0 12115), and the University of Pretoria RDP grant and the South African ENT Society Research Grant to RI Kabahuma. 


\section{References}

Abe, S., Usami, S., Shinkawa, H., Kelley, P.M., Kimberling, W.J., 2000. Prevalent connexin 26 gene (GJB2) mutations in Japanese. J. Med. Genet. 37, 41-43.

Adeoye, A.O., 2002. Goldenhar' s syndrome: case report. East Afr. Med. J. 79, 502-504.

Bademci, G., Cengiz, F.B., Foster Ii, J., Duman, D., Sennaroglu, L., Diaz-Horta, O., Atik, T., Kirazli, T., Olgun, L., Alper, H., Menendez, I., Loclar, I., Sennaroglu, G., Tokgoz-Yilmaz, S., Guo, S., Olgun, Y., Mahdieh, N., Bonyadi, M., Bozan, N., Ayral, A., Ozkinay, F., YildirimBaylan, M., Blanton, S.H., Tekin, M., 2016. Variations in multiple syndromic deafness genes mimic non-syndromic hearing loss. Sci. Rep. 6, 31622.

Barruet, K., Saka, B., Kombate, K., Mouhari-Toure, A., Nguepmeni Noune, J., Akakpo, S., Tchangai-Walla, K., Pitche, P., 2011. Keratitis-ich thyosis-deafness (KID) syndrome: an observation in a child in sub-Saharan Africa. Ann. Dermatol. Venereol. 138, 453-455.

Batissoco, A.C., Abreu-Silva, R.S., Braga, M.C., Lezirovitz, K., Della-Rosa, V., Alfredo, T., Jr., Otto, P.A., Mingroni-Netto, R.C., 2009. Prevalence of GJB2 (connexin-26) and GJB6 (connexin30) mutations in a cohort of 300 Brazilian hearing-impaired individuals: implications for diagnosis and genetic counseling. Ear Hear. 30, 1-7.

Beighton, P., Viljoen, D., Winship, I., Beighton, G., Sellars, S., 1991. Profound childhood deafness in southern Africa. Ann. N. Y. Acad. Sci. 630, 290-291.

Bosch, J., Noubiap, J.J., Dandara, C., Makubalo, N., Wright, G., Entfellner, J.B., Tiffin, N., Wonkam, A., 2014. Sequencing of GJB2 in Cameroonians and Black South Africans and comparison to 1000 genomes project data support need to revise strategy for discovery of nonsyndromic deafness genes in Africans. OMICS 18, 705-710.

Brobby, G.W., Muller-Myhsok, B., Horstmann, R.D., 1998. Connexin 26 R143W mutation associated with recessive nonsyndromic sensorineural deafness in Africa. N. Engl. J. Med. 338, 548-550. 
Chan, D.K., Chang, K.W., 2014. GJB2-associated hearing loss: systematic review of worldwide prevalence, genotype, and auditory phenotype. Laryngoscope 124, E34-53.

Dai, P., Yu, F., Han, B., Liu, X., Wang, G., Li, Q., Yuan, Y., Liu, X., Huang, D., Kang, D., Zhang, X., Yuan, H., Yao, K., Hao, J., He, J., He, Y., Wang, Y., Ye, Q., Yu, Y., Lin, H., Liu, L., Deng, W., Zhu, X., You, Y., Cui, J., Hou, N., Xu, X., Zhang, J., Tang, L., Song, R., Lin, Y., Sun, S., Zhang, R., Wu, H., Ma, Y., Zhu, S., Wu, B.L., Han, D., Wong, L.J., 2009. GJB2 mutation spectrum in 2,063 Chinese patients with nonsyndromic hearing impairment. J. Transl. Med. 7, 26.

Del Castillo, I., Moreno-Pelayo, M.A., Del Castillo, F.J., Brownstein, Z., Marlin, S., Adina, Q., Cockburn, D.J., Pandya, A., Siemering, K.R., Chamberlin, G.P., Ballana, E., Wuyts, W., MacielGuerra, A.T., Alvarez, A., Villamar, M., Shohat, M., Abeliovich, D., Dahl, H.H., Estivill, X., Gasparini, P., Hutchin, T., Nance, W.E., Sartorato, E.L., Smith, R.J., Van Camp, G., Avraham, K.B., Petit, C., Moreno, F., 2003. Prevalence and evolutionary origins of the del(GJB6D13S1830) mutation in the DFNB1 locus in hearing-impaired subjects: a multicenter study. Am. J. Hum. Genet. 73, 1452-1458.

Estivill, X., Fortina, P., Surrey, S., Rabionet, R., Melchionda, S., D' Agruma, L., Mansfield, E., Rappaport, E., Govea, N., Mila, M., Zelante, L., Gasparini, P., 1998. Connexin-26 mutations in sporadic and inherited sensorineural deafness. Lancet 351, 394-398.

Friderichs, N., Swanepoel, D., Hall, J.W., 3rd, 2012. Efficacy of a community-based infant hearing screening program utilizing existing clinic personnel in Western Cape, South Africa. Int. J. Pediatr. Otorhinolaryngol. 76, 552-559.

Gardner, J.C., Goliath, R., Viljoen, D., Sellars, S., Cortopassi, G., Hutchin, T., Greenberg, J., Beighton, P., 1997. Familial streptomycin ototoxicity in a South African family: a mitochondrial disorder. J. Med. Genet. 34, 904-906.

Gasmelseed, N.M., Schmidt, M., Magzoub, M.M., Macharia, M., Elmustafa, O.M., Ototo, B., Winkler, E., Ruge, G., Horstmann, R.D., Meyer, C.G., 2004. Low frequency of deafness- 
associated GJB2 variants in Kenya and Sudan and novel GJB2 variants. Hum. Mutat. 23, 206207.

Gasparini, P., Estivill, X., Volpini, V., Totaro, A., Castellvi-Bel, S., Govea, N., Mila, M., Della Monica, M., Ventruto, V., De Benedetto, M., Stanziale, P., Zelante, L., Mansfield, E.S., Sandkuijl, L., Surrey, S., Fortina, P., 1997. Linkage of DFNB1 to non-syndromic neurosensory autosomal-recessive deafness in Mediterranean families. Eur. J. Hum. Genet. 5, 83-88.

Gasparini, P., Rabionet, R., Barbujani, G., Melchionda, S., Petersen, M., Brondum-Nielsen, K., Metspalu, A., Oitmaa, E., Pisano, M., Fortina, P., Zelante, L., Estivill, X., 2000. High carrier frequency of the $35 \mathrm{delG}$ deafness mutation in European populations. Genetic Analysis Consortium of GJB2 35delG. Eur. J. Hum. Genet. 8, 19-23.

Hamelmann, C., Amedofu, G.K., Albrecht, K., Muntau, B., Gelhaus, A., Brobby, G.W., Horstmann, R.D., 2001. Pattern of connexin 26 (GJB2) mutations causing sensorineural hearing impairment in Ghana. Hum. Mutat. 18, 84-85.

Henn, B.M., Botigue, L.R., Gravel, S., Wang, W., Brisbin, A., Byrnes, J.K., Fadhlaoui-Zid, K., Zalloua, P.A., Moreno-Estrada, A., Bertranpetit, J., Bustamante, C.D., Comas, D., 2012. Genomic ancestry of North Africans supports back-to-Africa migrations. PLoS Genet. 8, e1002397.

Idan, N., Brownstein, Z., Shivatzki, S., Avraham, K.B., 2013. Advances in genetic diagnostics for hereditary hearing loss. J. Basic Clin. Physiol. Pharmacol. 24, 165-170.

Javidnia, H., Carson, N., Awubwa, M., Byaruhanga, R., Mack, D., Vaccani, J.P., 2014. Connexin gene mutations among Ugandan patients with nonsyndromic sensorineural hearing loss. Laryngoscope 124, E373-376.

Jonard, L., Feldmann, D., Parsy, C., Freitag, S., Sinico, M., Koval, C., Grati, M., Couderc, R., Denoyelle, F., Bodemer, C., Marlin, S., Hadj-Rabia, S., 2008. A familial case of Keratitis- 
Ichthyosis-Deafness (KID) syndrome with the GJB2 mutation G45E. Eur. J. Med. Genet. 51, 3543.

Kabahuma, R.I., Ouyang, X., Du, L.L., Yan, D., Hutchin, T., Ramsay, M., Penn, C., Liu, X.Z., 2011. Absence of GJB2 gene mutations, the GJB6 deletion (GJB6-D13S1830) and four common mitochondrial mutations in nonsyndromic genetic hearing loss in a South African population. Int. J. Pediatr. Otorhinolaryngol. 75, 611-617.

Keats, B.J., Berlin, C.I., 1999. Genomics and hearing impairment. Genome Res. 9, 7-16.

Kelley, P.M., Harris, D.J., Comer, B.C., Askew, J.W., Fowler, T., Smith, S.D., Kimberling, W.J., 1998. Novel mutations in the connexin 26 gene (GJB2) that cause autosomal recessive (DFNB1) hearing loss. Am. J. Hum. Genet. 62, 792-799.

Kelsell, D.P., Dunlop, J., Stevens, H.P., Lench, N.J., Liang, J.N., Parry, G., Mueller, R.F., Leigh, I.M., 1997. Connexin 26 mutations in hereditary non-syndromic sensorineural deafness. Nature $387,80-83$.

Kombate, K., Saka, B., Landoh, D.E., Mouhari-Toure, A., Akakpo, S., Belei, E., Gnassingbe, W., Djibril, M.A., Tchangai-Walla, K., Pitche, P., 2015. Keratitis-Ichthyosis-Deafness syndrome (KID) in a Togolese child born from a consanguineous marriage. Pan Afr. Med. J. 21, 266.

Lasisi, A.O., Bademci, G., Foster, J., 2nd, Blanton, S., Tekin, M., 2014. Common genes for nonsyndromic deafness are uncommon in sub-Saharan Africa: a report from Nigeria. Int. J. Pediatr. Otorhinolaryngol. 78, 1870-1873.

le Roux, T., Swanepoel de, W., Louw, A., Vinck, B., Tshifularo, M., 2015. Profound childhood hearing loss in a South Africa cohort: risk profile, diagnosis and age of intervention. Int. J. Pediatr. Otorhinolaryngol. 79, 8-14.

Lebeko, K., Bosch, J., Noubiap, J.J., Dandara, C., Wonkam, A., 2015. Genetics of hearing loss in Africans: use of next generation sequencing is the best way forward. Pan Afr. Med. J. 20, 383. 
Levin, S.E., Klugman, L.H., 1966. Pendred's syndrome in South African Bantu brothers. S. Afr. Med. J. 40, 759-760.

Massoure, P.L., Latremouille, C., Lamblin, G., Leca, F., 2012. LEOPARD syndrome. Cardiovasc J. Afr. 23, e19-20.

McPherson, B., Holborow, C.A., 1985. A study of deafness in West Africa: the Gambian Hearing Health Project. Int. J. Pediatr. Otorhinolaryngol. 10, 115-135.

McPherson, B., Swart, S.M., 1997. Childhood hearing loss in sub-Saharan Africa: a review and recommendations. Int. J. Pediatr. Otorhinolaryngol. 40, 1-18.

Morell, R.J., Kim, H.J., Hood, L.J., Goforth, L., Friderici, K., Fisher, R., Van Camp, G., Berlin, C.I., Oddoux, C., Ostrer, H., Keats, B., Friedman, T.B., 1998. Mutations in the connexin 26 gene (GJB2) among Ashkenazi Jews with nonsyndromic recessive deafness. N. Engl. J. Med. 339, 1500-1505.

Mustapha, M., Salem, N., Delague, V., Chouery, E., Ghassibeh, M., Rai, M., Loiselet, J., Petit, C., Megarbane, A., 2001. Autosomal recessive non-syndromic hearing loss in the Lebanese population: prevalence of the $30 \mathrm{delG}$ mutation and report of two novel mutations in the connexin 26 (GJB2) gene. J. Med. Genet. 38, E36.

Naidoo, L.C., Stephen, L.X., 1998. Congenital ameloblastic fibroma in association with oculoauriculovertebral spectrum. Int. J. Pediatr. Otorhinolaryngol. 43, 283-288.

Noubiap, J.-J.N., Djomou, F., Njock, R., Toure, G.B., Wonkam, A., 2014. Waardenburg syndrome in childhood deafness in Cameroon. S. Afr. J. Child Health 8, 3-5.

Oliveira, C.A., Alexandrino, F., Abe-Sandes, K., Silva, W.A., Jr., Maciel-Guerra, A.T., Magna, L.A., Sartorato, E.L., 2004. Frequency of the 35delG mutation in the GJB2 gene in samples of European, Asian, and African Brazilians. Hum. Biol. 76, 313-316. 
Pandya, A., Arnos, K.S., Xia, X.J., Welch, K.O., Blanton, S.H., Friedman, T.B., Garcia Sanchez, G., Liu, M.X., Morell, R., Nance, W.E., 2003. Frequency and distribution of GJB2 (connexin 26) and GJB6 (connexin 30) mutations in a large North American repository of deaf probands. Genet. Med. 5, 295-303.

Park, H.J., Hahn, S.H., Chun, Y.M., Park, K., Kim, H.N., 2000. Connexin26 mutations associated with nonsyndromic hearing loss. The Laryngoscope 110, 1535-1538.

Roberts, L., George, S., Greenberg, J., Ramesar, R.S., 2015. A founder mutation in MYO7A underlies a significant proportion of Ushersyndrome in indigenous South Africans: implications for the African diaspora. Invest. Ophthalmol. Vis. Sci. 56, 6671-6678.

Samanich, J., Lowes, C., Burk, R., Shanske, S., Lu, J., Shanske, A., Morrow, B.E., 2007. Mutations in GJB2, GJB6, and mitochondrial DNA are rare in African American and Caribbean Hispanic individuals with hearing impairment. Am. J. Med. Genet. A 143A, 830-838.

Sellars, S., Beighton, P., 1983. The Waardenburg syndrome in deaf children in southern Africa. S. Afr. Med. J. 63, 725-728.

Shearer, A.E., Black-Ziegelbein, E.A., Hildebrand, M.S., Eppsteiner, R.W., Ravi, H., Joshi, S., Guiffre, A.C., Sloan, C.M., Happe, S., Howard, S.D., Novak, B., Deluca, A.P., Taylor, K.R., Scheetz, T.E., Braun, T.A., Casavant, T.L., Kimberling, W.J., Leproust, E.M., Smith, R.J., 2013. Advancing genetic testing for deafness with genomic technology. J. Med. Genet. 50, 627-634.

Trotta, L., Iacona, E., Primignani, P., Castorina, P., Radaelli, C., Del Bo, L., Coviello, D., Ambrosetti, U., 2011. GJB2 and MTRNR1 contributions in children with hearing impairment from Northern Cameroon. Int. J. Audiol. 50, 133-138.

Van Camp, G., Willems, P.J., Smith, R.J., 1997. Nonsyndromic hearing impairment: unparalleled heterogeneity. Am. J. Hum. Genet. 60, 758-764. 
van der Walt, E.M., Smuts, I., Taylor, R.W., Elson, J.L., Turnbull, D.M., Louw, R., van der Westhuizen, F.H., 2012. Characterization of mtDNA variation in a cohort of South African paediatric patients with mitochondrial disease. Eur. J. Hum. Genet. 20, 650-656.

Wonkam, A., Bosch, J., Noubiap, J.J., Lebeko, K., Makubalo, N., Dandara, C., 2015. No evidence for clinical utility in investigating the connexin genes GJB2, GJB6 and GJA1 in nonsyndromic hearing loss in black Africans. S. Afr. Med. J. 105, 23-26.

Wonkam, A., Noubiap, J.J., Djomou, F., Fieggen, K., Njock, R., Toure, G.B., 2013. Aetiology of childhood hearing loss in Cameroon (sub-Saharan Africa). Eur. J. Med .Genet. 56, 20-25.

Yan, D., Park, H.J., Ouyang, X.M., Pandya, A., Doi, K., Erdenetungalag, R., Du, L.L., Matsushiro, N., Nance, W.E., Griffith, A.J., Liu, X.Z., 2003. Evidence of a founder effect for the 235delC mutation of GJB2 (connexin 26) in east Asians. Hum. Genet. 114, 44-50.

Yan, D., Tekin, D., Bademci, G., Foster, J., 2nd, Cengiz, F.B., Kannan-Sundhari, A., Guo, S., Mittal, R., Zou, B., Grati, M., Kabahuma, R.I., Kameswaran, M., Lasisi, T.J., Adedeji, W.A., Lasisi, A.O., Menendez, I., Herrera, M., Carranza, C., Maroofian, R., Crosby, A.H., Bensaid, M., Masmoudi, S., Behnam, M., Mojarrad, M., Feng, Y., Duman, D., Mawla, A.M., Nord, A.S., Blanton, S.H., Liu, X.Z., Tekin, M., 2016. Spectrum of DNA variants for non-syndromic deafness in a large cohort from multiple continents. Hum. Genet. 135, 953-961.

Zelante, L., Gasparini, P., Estivill, X., Melchionda, S., D' Agruma, L., Govea, N., Mila, M., Monica, M.D., Lutfi, J., Shohat, M., Mansfield, E., Delgrosso, K., Rappaport, E., Surrey, S., Fortina, P., 1997. Connexin26 mutations associated with the most common form of nonsyndromic neurosensory autosomal recessive deafness (DFNB1) in Mediterraneans. Hum. Mol. Genet. 6, 1605-1609. 